\title{
Comparative Study on Start-up Business Incubator Construction Case Study on Incubators in Tianjin
}

\author{
Li Zhe \\ School of Economics and Management, \\ Tianjin Institute of Urban Construction \\ Tianjin, China \\ lizheteacher@126.com
}

\begin{abstract}
To start and develop a new enterprise is limited by various factors due to the uncertainties in such aspects as technique, capital, market and management. Business incubators are an effective way to drive a new-starting enterprise to be developed and mature in a short time. In this paper, through analyzing the successful experience of building incubators for start-up enterprise home and abroad, and based on the status quo in Tianjin, some inspirations on incubator construction are drawn for governments, associations, colleges and universities and other organizations who give their support in this effort.
\end{abstract}

Keywords- Start-up Business; Incubator; Tianjin

\section{INTRODUCTION}

Starting a business is developing vigorously and writing a myth of wealth, employment and growth in today's world. Everyone having the right to start a new business or enterprise is not only a project of enriching people, but also an important project of improving employment and boosting the construction of a harmonious society. Start-up enterprises refer to the innovative pioneering ones in their starting stage. High-profit, high-growth and high-risk are three characteristics of start-up enterprises because of the uncertainties in their outputting and innovating. Aiming to promote the commercialization of research findings and development of S\&T enterprises, incubators are S\&T service organizations for social public welfare which provide various services for start-up enterprises' development and push these enterprises grow quickly. Business incubator is a cradle for start-up enterprises for they create a favorable environment for start-up enterprises through providing public conditions and services such as places, technology, consulting, financing and training to reduce the risk of starting a new business and improve their rate of success, therefore, incubator construction of is a key in the growth of start-up enterprises.

\section{THE PRACTICE AND EXPERIENCE OF SUPPORTING THE INCUBATOR CONSTRUCTION FOR START-UP ENTERPRISES HOME AND ABROAD}

\section{A. Business Incubator Supported by Governments in USA}

Business incubators originated from America in 1950s and American incubator ranks the first all over the world. Funds of these incubators are mainly from the federation government, state and local governments. Besides, Federal Economic Development Committee allocates funds regularly and the incubators are also supported by matching funds. The support from US government can be divided into two forms: formal and informal. Formal support policies include the legal allocation of funds from the federal for the infrastructure of incubators, the competitiveness funds for the federal to select incubators, matching funds of support service for new enterprises and the funds established by Federal Economic Development Committee. Informal ones cover tax exemption for enterprises investing on incubators, low-interest loan, private funds in joint enterprises, banks' operation funds and so on. Besides, there are projects of seed funding for a few incubators.

\section{B. Brazilian Business Incubators Supported by} Universities or Colleges and Enterprises

Brazilian business incubators develop so fast that the number of incubators ranks the fourth, following USA, China and Germany. The funds mainly come from universities, colleges and enterprises though their governments have a share. In Brazil, government funds are prohibited being used to directly support enterprises by the law, so it is difficult for new start-up enterprises obtain loans. Therefore, the cooperation between universities (or colleges) and enterprises enables government funds for universities (colleges) to fund enterprises through supporting the incubator or other projects.

\section{British Business Incubators with Many Supports}

The development of British business incubators started in early 1980s. British governments set up particularly incubator funds in Small Business Administration and established incubators with local Development Agencies and related local organs to provide work space and support for start-up enterprises. Local innovation funds from governments built incubators' feasibility research grant for the development of incubators through providing funds for organizations in need. Part of allocations from EU's European Structural Funds (including European Social Fund and European Local Development fund) are used to incubator construction. Thanks to these funds, more than 200 incubator bases have been established in Britain up to now.

\section{Incubator Network with Rapid Development in Beijing}

In September, 2000, with the guidance and support of Beijing Municipal Science and Technology Commission, 
Beijing High Technology Innovation Service Center took the lead to establish Beijing Association of Incubators for Startup Enterprises with the hands of each incubator institutes in Beijing, Intermediary Consulting Services, Venture Capital Institutions, Scientific Research Institutes and High and New Technology enterprises. All of the enterprises' incubator organizations in Beijing are accepted as a member of this association. Thus, a new network of business incubator was taken shape, which really promotes the establishment and development of various business incubators in Beijing and creates the growth source of high and new technology industry. Beijing Hi-tech Business Innovation Service Center, Beijing International Business Incubator Center, Haidian Innovation Service Center in Zhong Guancun S\&T Park, Tsinghua Innovation Park and others are developing at a fast pace, which create an excellent environment for start-up enterprises in different areas of Beijing.

\section{E. Maturely-developed Colleges and Universities Incubators in Shanghai}

Since the establishment of national science park in Shanghai University in 1991, 9 national science parks have been built in universities such as Fudan University, Shanghai Jiao Tong University, Shanghai University of Finance and Economics. Because colleges and universities incubators are located on the campus or nearby, besides the common plays of ordinary business incubators, in these incubators, incubating enterprises can use libraries, laboratories, large computer systems in these colleges and universities, can consult experts of each school and faculty professional issues, can employ university students and can cooperate with colleges and universities in scientific researches; what's more, they can commercialize scientific findings by colleges and universities. According to their own advantages, colleges and universities in Shanghai create S\&T Park, making a great contribution in improving innovating ability in each area, stabling and developing start-up enterprises and economic development in each area.

\section{RESEARCH ON THE STATUS QUO OF START-UP BUSINESS INCUBATOR CONSTRUCTION SUPPORTED BY TIANJIN}

\section{A. The Status Quo}

With the advancing of opening-up and reform, incubators are set up in Tianjin. Science and technology innovation service business have achieved a great development in the content and forms as well as in kinds and the member in recent years. There are over 100 unique incubators of which 11 are national incubators, 12 are municipal ones and 45 have been accredited. Currently, the total area of incubators in Tianjin covers 1.42 million m2 and 2790 start-up enterprises have been accommodated in these incubators, which have created more than 70, 000 jobs. Statistics from 3 incubators of S\& T Commission, New Technology Industrial Park and Development Zone show that more than 500 high and new technology achievements have been realized. These achievements cover a wide range of new and high technology field such as new energies, computer software and network technology, bioengineering and new medicine, environmental technologies and so on.

\section{B. Characteristics of Start-up Business Incubators Construction in Tianjin Municipality}

\section{Diversified Business Models}

With the increase in the number of incubators in Tianjin, the operation models begin to be diversified. Currently, 7 kinds of incubators mainly exist: Government Demonstration S\&T Business incubators (Tianjin Municipal Science and Technology Innovation Service Center), Start-up S\&T Business Incubators of Listed Company (Tianjin Hi-Tech Development Co.,Ltd), S\&T Business incubators of Special Industries in Districts and Counties (Tianjin Tian-Gan Digital Image and Video Industry Incubator in Hexi), Private S\&T Business Incubators (Tianjin Kaitai Business Incubation CO., LTD. in the Development Zone and CENDRAGON in Heping district), Investment-oriented S\%T Business Incubators (Biological Medicine Incubator of TEDA VENTURE CAPITAL CORPORATION LIMITED ), Joint S\&T Business Incubators of Foreign Countries and Colleges and Universities (International Biological Pharmaceutical Innovation Park), S\&T Business Incubators by Colleges and Universities (S\&T Park of Civil Aviation University of China). Most of them serve the start-up business.

\section{Specialized Content}

The proportion of specialized incubators in Tianjin is increasing day by day. They are covering the competitive industries in Tianjin such as Biomedicine, cultural innovation, electronic information, petrochemical engineering, energy conservation and environment protection. The special incubators such as S\&T Park of Tianjin Polytechnic University, Tianjin Municipal Foreign Trade Pioneer Park, Tianjin Huanyuan Software Park, National Incubator for Software Expert, National Incubator of "863" Software, National Torch-Plan Software Industry have formed an industrial cluster, which facilitates the effective fuse between service cluster and industry cluster by large-scale developing and greatly boosts the development of high-tech start-up business.

\section{Supported by Governments}

The recent development momentum of incubators in Tianjin attributes to the attention of Tianjin municipality on it. The incubator construction has been greatly improved with the guidance of scientific planning and the backup of supporting policies. The establishment of Association for Promoting the Development of Tianjin Municipality S\&T Business Incubators in 2007 plays a significant role in accelerating the development of Tianjin start-up business and incubators. Since the introduction and implementation of Growth Plan for Tianjin Municipal S\&T Little-Giant and To Improve the Development of Small and Medium-sized S\&T Enterprises by Tianjin Municipal government in September, 2010, start-up business and incubators began to develop rapidly. Tianjin Municipal government has also worked out performance indicator for incubators, evaluation system and methods of selecting outstanding incubators. 


\section{PROBLEMS IN START-UP BUSINESS INCUBATORS SUPPORTED BY TIANJIN MUNICIPALITY}

\section{A. Insufficient Financing Support of Incubators for Start-up Business}

Although the initial support fund and various Angel Fund have been set up for incubators to attract more talents and technological innovation, the problem of capital shortage prevails in many start-up businesses because the mature counterpart wins the flavor of governments who have to set up higher requirements of access threshold: more advanced technology, preliminary products and complete intellectual property rights for a more effective utility of local resources and avoiding investment risks. A successful example in investment operation of start-up business is Tianjin TEDA Pioneer Center who participates in the operation of technology risk fund of Tianjin Economic and Technology Development Zone. There is no start-up investment in almost other incubators in Tianjin, so they are lagged behind other provinces and municipalities such as Shanghai, Jiangsu, Wuhan and Xi' an in their service of providing financing for high and new tech enterprises.

\section{B. Lacking of Effective Communication and Cooperation between Related Organizations}

A complete S\&T innovative incubating system integrating Incubator Service, venture capital market and information network construction has not really established because of the shortage of effective communication and cooperation between incubators and other S\&T services. Incubation institutions are the core of the innovative incubating system, so productivity promotion center and other S\&T intermediary service organizations are the pillar of this system. For a long time, with the absence of a sound system and uniform supervision and management, there are overlaps in the functions within and between each service organization in Tianjin, so they cannot have developed their competitiveness of an effective cooperation and integration, nor can they complement each other.

\section{Imperfect Functions of Association}

The equations are an exception to the prescribed The major functions of Association for Promoting the Development of Tianjin Municipality S\&T Business Incubators are to do publicity work, counsel and hold training, to provide information service and to work out assessment and evaluation. Though many incubators have been built, operated and managed according to Standards, and they have been accredited to the municipal or national standard, the contact between business incubators and intermediary service organizations, risk investment organizations and scientific organizations are far from being in-depth. Besides, such associations have not played a role in cultivating entrepreneurs and building new small-sized hightech enterprises and speeding up commercialization of scientific findings.

\section{INSPIRATIONS FOR THE CONSTRUCTION OF START-UP BUSINESS INCUBATOR SUPPORTED BY TIANJIN MUNICIPALITY}

\section{A. To Maintain the Forceful Support of Governments}

The supports of governments for incubators are mainly realized through policies and financial support. Governments should issue favorable policies at the right time to encourage science and technology start-up business, support the development of various incubators, and retain their unique competitiveness of each incubator and proper competition. With other departments concerned, they should also put the policy of tax return for incubators into effect; make the construction of Centre for Entrepreneurship, the quantity and quality as important indicators to assess the performance of related departments and to demonstrate the competitiveness of each area respectively; departments of all levels in a government should establish regulations and rules for starting business incubators and offer financial support for them.

\section{B. To Increase Financial Support for Start-up Business}

In practice, there are some controversies over incubator's investment on start-up business. From the perspective of reducing the cost of entrusting agents, proper investment should be encouraged. Qualified incubators can take the lead to introduce the mechanism of risk investment, to help other enterprises open more financing channels and launch steadily the construction of investment and financing system such as funds, guarantee and share to specify a standard venture capital investment. Meanwhile, they are supposed to create conditions for incubating enterprises to report the innovation fund for S\&T medium and small-sized enterprises.

\section{To Promote the Role of Associations}

Association for Promoting the Development of Tianjin Municipality S\&T Business Incubators is not only a selfregulatory organization, but also an organization in charge of making regulations and rules, industry coordination and proceeding as well as assist governments in building an optimal environment for the growth of business incubators. Along with its duty to publicize, counsel, hold training, provide information service, this association should strengthen the contact between business incubators and intermediary service organizations, risk investment institutions and scientific research institutes. It is also supposed to improve the business incubator's ability to have dialogue with governments and to strive for a favorable policy environment for the development of this industry.

D. To Push Forward the Role of Colleges and Universities' in incubating Start-up Business

The early development of many start-up businesses is a system project needs capital and team. However, high-end talents and enterprises may not have support in this stage, which is the major bottle-neck for the development of startup business and small S\&T enterprises. Most of the scientific technology resources are concentrated in colleges and universities, so these resources must be development fully and utilized effectively to deepen the industry-university- 
research cooperation with the significant strategy of propelling science and technology innovation in enterprises. College and university incubators will provide an effective mechanism to promote and develop the system of science and technology innovation where enterprises are the major participant through opening science and technology resources in colleges and universities, catalyzing and cradling start-up business and deepening the industryuniversity-research cooperation.

\section{REFERENCES}

[1] Shaoying Zhang, "Development Trend and Countermeasure selection of Science-and-Technology Business Incubators.” [J] Modern Science, 2010(3):110-112.

[2] Lingjuan Xv, Ninghui Liu, "Study on Internal Correlation Mechanism between Science-and-Technology Business Incubators and Regional
Economic Development.” [J] Journal of Nanjing University of Aeronautics and Astronautics, 2010(3):31-35.

[3] Liming Zhao, Fei Xie, "Analysis on Cooperation between Scienceand-Technology Business Incubators and Start-up Enterprises.” [J] Science \& Technology Progress and Policy, 2010 (3): 90-92.

[4] Guanshi Zhao, "Comparing and Inspirations from Entrepreneurship Education of University Students in USA, Sweden and India.” [J] Education Research Monthly, 2009(5):62- 64.

[5] Liang Ma, "Introduction to Entrepreneurship Education in EU Countries.” [J] China Labor, 2009(8):31- 34.

[6] Xuemei Li, "Inspirations from Abroad Entrepreneurship Education for Entrepreneurship Education in Higher Vocational Colleges in Anhui Province.” [J] Journal of HuaiNan Teachers College, 2009(3):14- 117. 